\title{
Potential impacts of a widespread subplinian andesitic eruption from Tongariro volcano, based on a study of the Poutu Lapilli.
}

\author{
D.W.HITCHCOCK \\ J.W.COLE \\ Department of Geological Sciences, \\ University of Canterbury \\ Private Bag 4800 \\ CHRISTCHURCH \\ New Zealand
}

\begin{abstract}
Recent eruptions from Tongariro volcano, particularly from Ngauruhoe, have been small (Volcanic Explosivity Index or VEI $\leq 3$ ), but between 11,000-12,000 calendar years BP there was a series of larger subplinian eruptions (VEI 4) from Tongariro volcano (Mangamate Formation), the last of which formed the Poutu Lapilli. This unit is considered to have had a volume of $1.1 \mathrm{~km}^{3}$, distributed in three main lobes (NW, NE, E) around a possible source or sources close to the present site of Ngauruhoe. Column height during the eruption ranged from 16 to $23 \mathrm{~km}$. If such an eruption occurred today it would have a significant impact on the surrounding area. In the proximal zone $(<25 \mathrm{~km}$ from source) $>20 \mathrm{~cm}$ of ash/lapilli would be deposited, sufficient to cause collapse of some buildings in Tokaanu and the surrounding communities and damage to the Tokaanu Power Station. Much of the other infrastructure in the area (e.g electricity transmission lines, water supply and distribution, roads) would also be affected, as would the tourist industry. Evacuation may be necessary from this proximal area, and plans for this should be drawn up well before the event. Adequate provision also has to be made for disposal of ash from towns/communities and from key roads. Medial and distal areas (up to $100 \mathrm{~km}$ from source) would be affected, but to a decreasing extent with distance from source. An eruption like that forming the Poutu Lapilli is possible at any time in the future from Tongariro, and it is important that an effective management system is put in place to deal with such an event.
\end{abstract}

Keywords volcanic hazards; effects on infrastructure; subplinian eruption; Poutu Lapilli; Tongariro

\section{INTRODUCTION}

The Tongariro volcanic massif (hereafter referred to as Tongariro) has been active for at least 260 +/- 3 ka (Hobden et al 1999) and during this time has erupted predominantly basaltic andesite and andesite lavas and pyroclastic deposits, which together with accompanying debris avalanches and lahar deposits, have a volume of c. $75 \mathrm{~km}^{3}$ (Hobden 1997). There has been a series of vigorous growth periods, particularly at 210-200 ka, 130-70 ka and <25 ka (Hobden et al 1999). Older vents and deposits are now predominantly covered by younger volcanic units, although there is some indication of a northwest-southeast alignment of older vents across central Tongariro (Mathews 1967; Cole et al 1986). During the last $15 \mathrm{ka}$, vents have been aligned along a $25 \mathrm{~km}$ northwest- 
southeast trending zone represented partly by a graben structure bounded by major normal faults. Nairn et al (1998) studied proximal deposits of the Mangamate Formation, and the 10 ka Ruapehusourced Pahoka Tephra. They identified the Pahoka-Mangamate sequence as seven units, PM1PM6. Two additional unnamed andesitic, and three silicic, tephra deposits (Opepe, Poronui and Karapiti tephras) are also within this formation. These have aided the dating of individual units found within the sequence (Table 1). Nairn et al. (1998) proposed that PM1-PM6 came from multiple vents on and surrounding Tongariro, and that they were erupted sequentially or simultaneously, each within a 200-400 yr duration. In historic times (from 1839 to 1975) there have been $>85$ volcanic eruptions from Tongariro, including Ngauruhoe (Siebert \& Simkin, 2002), but most of these have been small (VEI $\leq 3)$. Figure 1 shows the main historic and pre-historic eruptive vents from Tongariro. Eruptions from the historic sites have produced minor hazards and a minimal impacts on the region compared with the risks from larger pre-historic eruptions.

This study takes one of the Mangamate Formation members, the c. 11,000 years BP Poutu Lapilli (PM6), as an example of a large subplinian eruption (VEI 4), establishes its distribution and eruption dynamics, then evaluates the likely impact of a similar-sized eruption on today's central North Island infrastructure.

\section{POUTU LAPILLI}

Field mapping and sample collection of bulk pyroclastic fall samples, and lithic clasts of the Poutu Lapilli were used to produce an isopach (Fig. 2) and two isopleth (Fig. 3) maps. Thicknesses were measured at 110 locations, and six maximum lithic clasts were collected from each outcrop and their $a$ and $c$ axes measured. Ash/lapilli density measurements were also obtained to support modelling of physical loading of roofs and structures. There are three main areas of deposition, forming northwestern, northeastern, and eastern lobes, with a smaller lobe to the southeast (Fig. 2). Outcrops consist of massive lapilli and/or ash units and multiple graded beds with variation in the number of showerbeds and their thickness from one outcrop to the next. Post-deposition erosion of the upper contact throughout the field area suggests that thickness measurements are minima, and accounts for some irregularities in isopachs on Fig. 2. In proximal and distal areas, erosion and admixing with soils makes precise thickness determination difficult.

Distal tephra-fall data for the Poutu Lapilli were sourced from studies of lake sediments from Waikato lakes. Lowe et al (1980) and Lowe (1988) established that 11 ash and lapilli layers from 
Tongariro were preserved in the lakes and that one of the Tongariro-derived tephras was a member of the Mangamate Formation, possibly Te Rato Lapilli. Subsequently, Donoghue et al (1991) used olivine composition and morphology to demonstrate that Waihohonu Lapilli rather then Te Rato Lapilli was the likely member correlative. At Lake Maratoto (NZMS260 1:50,000, S15/129663) Lowe et al (1980) measured c. $4 \mathrm{~cm}$ of Mangamate tephra, and samples above were radiocarbon $\left({ }^{14} \mathrm{C}\right)$ dated at $9700 \pm 140$ and 10,120 \pm 100 years BP respectively (Table 1). Using SHCa104 (McCormac et al., 2004) amd OxCal3 (Bronk Ramsey, 2001) these ${ }^{14} \mathrm{C}$ ages represent a calendar age of between 11,000 and 12,000 calendar years BP. Poutu Lapilli is at the younger end of the range and is estimated at 11,000 calendar years BP (Table 1).

There is little difference in componentry and granulometry of each lobe; most outcrops are showerbedded, are normally graded upwards and have decreasing values of sorting and grain size. There are many lithics at the base of the basal showerbed in the northeastern lobe, whereas in the eastern and southeastern lobes the number of lithics is consistent throughout. The stratification of the normally graded coarse ash to lapilli material of the northwestern and northeastern lobes is evidence for an unsteady and fluctuating column.

A more detailed study was made of the northeastern lobe to determine tephra-fall impacts on the region. Location 2 (T2; Fig. 2), near the axis of the northeastern lobe, comprises five showerbeds AE (Fig. 4). These beds are unimodal and overall show a slight decrease in both median diameter and sorting of each individual showerbed upwards (Fig. 5). Bed A is interpreted as the initial conduitclearing phase because of the high concentration of lithic material included within it. The slightly larger median grain size of bed A, compared with the other beds at this location, indicates that this opening phase had the most energy. The normal grading of all beds indicates pulsation during the eruption, perhaps caused by eruption pressure decreasing or vent widening during each phase, or both.

\section{Volume}

Using the empirical method of Pyle (1989), modified by Fierstein \& Nathenson (1992), in which $\log$ thickness (from Fig. 2) is plotted against the square root of the area, volumes for each individual lobe (Northwest, Northeast and East) were calculated, then combined to give a value for the Poutu Lapilli deposit as a whole. This method gives a total volume of $1.1 \mathrm{~km}^{3}$ (Table 2) for the Poutu Lapilli eruption, compared with estimates of $1.2 \mathrm{~km}^{3}$ by Nairn et al (1998), and $0.9 \mathrm{~km}^{3}$ by Topping (1973) who used the method of Cole \& Stephenson (1972). The most limiting factors on the 
accuracy of the volume calculation are the lack of proximal and distal outcrops, and amount of erosion, both of which reduce the overall volume calculated. Minor overlap occurred at some lobe boundaries whereas at others there are gaps, but the effect of these on volume calculations are negligible.

\section{Column heights}

Table 3 shows calculations of eruption column height for the northwestern lobe, derived by closing the lithic isopleths shown in Fig. 3 and using the Pyle (1989) method of calculation. The calculations indicate a minimum $\mathrm{H}_{\mathrm{B}}$ (buoyancy height) value of $18.5 \mathrm{~km}$ for the eruption depositing the lobe. Of the three lobes, the northwestern is the best constrained with the lithic isopleth having a similar axis orientation and geometry. The northeastern lobe is more difficult to constrain with the lithic clasts because of the small number of data points, but has an averaged estimate for eruption column height $\left(\mathrm{H}_{\mathrm{B}}\right)$ of $23 \mathrm{~km}$. The eastern lobe is the least constrained, but gives a value of $\left(\mathrm{H}_{\mathrm{B}}\right) 16$ $\mathrm{km}$.

\section{Eruption classification}

Pyle (1989) revised the empirical method of pyroclastic fall classification of Walker $(1973,1980)$, and introduced the parameter of the half distance ratio $\left(b_{c} / b_{t}\right)$ which was plotted against the thickness half distance $\left(b_{t}\right)$. Figure 6 shows the plot of the northwestern, northeastern and eastern lobes of the Poutu Lapilli eruption. Included on the revised classification scheme is the dispersal index $\left(\mathrm{D}, \mathrm{km}^{2}\right)$ from the Walker (1980) classification. The northwestern and eastern lobes plot in the subplinian field, whereas the northeastern lobe plots just within the plinian field.

\section{TEPHRA-FALL IMPACTS}

The impact of a volcanic eruption on a community depends on the physical attributes of the eruption and the vulnerability of utilities and infrastructure of that community (Fig. 7). Detailed quantitative studies of ashfall impacts on communities and infrastructure are important but all previous studies related to the Tongariro area have been on smaller events, such as the 1945 and 1995/96 eruptions of Ruapehu (Johnston et al 2000). These events had minimal impact on the region compared with those that would have arisen during larger eruptions such as the Poutu event.

A Poutu-style subplinian eruption sourced from Tongariro volcano will have a dramatic impact on the regional and community infrastructure, and national lifelines, affecting many communities (Table 4). Direct impacts resulting from ashfall include damage or failure of infrastructure such as 
roofs and roads, as well as water supply depletion and/or contamination. Therefore, it is important to understand the vulnerability of infrastructure specific to regions and communities.

\section{IMPACT ZONES}

The proximal area for tephra-fall impact is regarded in this study as being within a $25 \mathrm{~km}$ radius from the probable source vents, normalised to a 'proto-Ngauruhoe' vent site, and incorporates infrastructure that is most heavily impacted from pyroclastic lapilli fall material. This $25 \mathrm{~km}$ impact zone (inset, Fig. 2, Fig. 7) has a minimum ashfall thickness of $40 \mathrm{~cm}$ along the lobe axis, and granulometric analysis indicates the tephra is largely fine to medium lapilli. The medial area is regarded as the $25-100 \mathrm{~km}$ radius from the source area (inset, Fig. 2) and has an ashfall thickness of $40-\sim 7 \mathrm{~cm}$ of fine lapilli to medium ash. The distal area is $>100 \mathrm{~km}$ radius from source (inset, Fig. 2) and it will experience deposition of medium to ultra-fine ash. A dominant southwesterly wind direction, similar to that which distributed the northeastern lobe of the Poutu Lapilli, will be used for the following impact assessment. This is similar to the dominant wind direction today (Johnston 1997a), although it is possible that winds were stronger at the time of the Poutu eruption (Shane 2007).

\section{GENERAL IMPACTS}

When the isopach map of the Poutu Lapilli is superimposed on the infrastructure, it shows that the communities of Turangi, Tokaanu, Waihi, and the smaller settlements of Tongariro, Otukou and Papakai are located within the proximal hazard zone (Fig. 7). The lithic isopleth map (Fig. 8) shows a more limited distribution but lithic fall would still have an impact on the communities of Papakai, Otukou and the Rangipo Power Station. The level and extent of these impacts will be discussed in more detail in the following sections.

\section{PROXIMAL IMPACTS}

\section{Buildings and structures}

Damage to buildings from tephra fall occurs in the following ways: directly from projectile impacts (penetration, denting and abrasion), collapse from roof loading, and indirect damage such as ignition from hot projectiles, corrosion from acidic ash coatings, and short-circuiting by fine ash causing fire (Blong 1984). Blong (1984) used snow deposition as a basis to characterise ashfall deposits on roofs identifying, among others, a range of factors: 
- accumulations on sloping roofs depend on the friction between the roof-tephra and grain-tograin tephra interface;

- roof loads may reach two or three times ground loads;

- unbalanced roof loads will cause stress on the internal supports and framing and result in failure. Spence et al (1996) surveyed the damage to buildings arising from the 1991 Pinatubo eruption, concluding that the nature of the roof supporting structure was the principal factor influencing partial or full collapse. Other factors were construction type and roof pitch. These findings were backed up by Pomonis et al (1999) who noted that the style and method of construction of the roof are the foremost factors affecting a building's resistance to heavy tephra loading. The effects of lapilli loading on roofs is likely to be similar to that from ash loading, although differences may result from greater thicknesses, increased weight by becoming wet, and different repose angles.

Tephra loading against vertical structures such as walls will cause stress and may cause structures to fail, especially those that have a large area crossing the path of the prevailing winds. Pomonis et al (1999), basing their observations on old-style buildings of Furnas (Azores), stated that complete collapse of old masonry houses with thick walls is possible by bomb impact and hinted that concrete block masonry may be more susceptible to these impacts. These authors favoured concrete block wall construction, abandoning timber frame construction.

The town that will be most affected by any Poutu-style eruption is Turangi. Approximately 850 of the residential properties there are remnant housing from the Tongariro Power Development scheme, built during the 1960s (Fig. 9), which account for c. 45\% of Turangi housing. These houses are constructed on concrete pile foundations with a light timber frame, weatherboard cladding and a corrugated iron roof. The roofs have a c. $20^{\circ}$ pitch, with internal roof construction using the rafter and purlin method.

Pomonis et al (1999) noted potential purlin (rather than rafter) failure under loads of ash, although Blong (2003) noted that the variability of timber strength may have been underestimated in that study. After the 1994 Rabaul eruption, Blong (2003) recognised that roof collapse at locations within the town of Rabaul was caused by both purlin and rafter failure under weights as minimal as $2-5 \mathrm{kN} / \mathrm{m}^{2}\left(204-510 \mathrm{~kg} / \mathrm{m}^{2}\right)$, although some roofs had withstood a load of $15 \mathrm{kN} / \mathrm{m}^{2}\left(1531 \mathrm{~kg} / \mathrm{m}^{2}\right)$. That study concluded that commonly timber-framed houses would need to be able to sustain ash loads of at least $7.5 \mathrm{kN} / \mathrm{m}^{2}\left(764 \mathrm{~kg} / \mathrm{m}^{2}\right)$ to avoid total failure. 
Using the density of dry and wet fallen lapilli material of the northeastern lobe and the lapilli thickness (Fig. 2), the live load of a similar lapilli fall on roofs in Turangi can be calculated using the equation of Johnston (1997a):

$$
L=\underline{\mathbf{d p g} g}
$$

$$
\begin{aligned}
& \mathrm{L}=\text { Ash load pressure }(\mathrm{kPa}) \\
& \mathrm{d}=\operatorname{ash} \text { depth }(\mathrm{m}) \\
& \mathrm{p}=\operatorname{density}\left(\mathrm{kg} / \mathrm{m}^{3}\right) \\
& \mathrm{g}=\text { gravitational acceleration }\left(\mathrm{m} / \mathrm{s}^{2}\right)
\end{aligned}
$$

Conversion of the ash load thickness from Blong (2003) for the 1994 Rabaul eruption to ash load pressure is compared with the potential ash load pressure on roofs for a Poutu-style eruption on Turangi (Table 5). Comparison of the values quoted by Blong (2003) and load capacities calculated for a Poutu-style eruption in Table $5\left(355-720 \mathrm{~kg} / \mathrm{m}^{2}\right)$ shows that the weight of up to $60 \mathrm{~cm}$ of tephra fall on Turangi roofs may not be sufficient to cause widespread collapse from a Poutu-style eruption, but may cause partial collapse and is near the total collapse threshold. This does not, however, take into account the variability of timber strength, timber size of purlins and method of loading. Nor does it take into account the variable nature of tephra fall such as density and degree of saturation.

Other houses in the Turangi area are a mixture of ages and construction styles. The majority are more modern homes, with a few older style (i.e., pre-1950) homes. The commercial premises of the Turangi shopping centre have low pitch or flat pitch roofs with moderate spans (c. $12 \mathrm{~m}$ ) and reasonable areas (c. $300 \mathrm{~m}^{2}$ ). Buildings with a larger roof area would be more susceptible to partial or total collapse depending on the construction method and material (i.e., steel frame as opposed to wood frame), and the spacing of purlins. Blong (2003) observed from the Rabaul eruption that steel-framed buildings performed no better than timber-framed commercial/industrial buildings - in some cases they may have been worse, because the steel-framed buildings had wider spans between roof trusses. Two buildings of interest in Turangi, important to any community, are the fire and ambulance stations. These have a low pitched-moderate spanned roof $\left(<20^{\circ}\right.$ at c. $\left.12 \mathrm{~m}\right)$ and a flat/low pitched short spanned $(<12 \mathrm{~m})$ roof, respectively, and would be prone to collapse in a Poutu-style eruption. 
Turangi would not be subjected to constant bombardment by lithic clasts, but may receive rare lithic fallout. Outlying smaller communities such as Otukou, Papakai, Taurewa, Rangipo, and the community on the southern edge of Lake Rotoaira, as well as receiving a large thickness of fallout lapilli, would also be subjected to falling lithic clasts. The maximum size of the falling clasts on the communities is c. $4.5 \mathrm{~cm}$ ( $a$ axis clast length) at Taurewa and Papakai. The physical impact of these clasts may cause penetration and denting of roofing material and wooden clad walls, and the pitting and abrasion of concrete block walls. Clasts lighter than $1000 \mathrm{~g}$ have been known to have penetrated galvanised iron roofs in the Azores (Pomonis et al 1999). If lithic bombardment were to occur at the start of an eruption sequence (i.e., equivalent to the opening eruption phase of the northeastern lobe in the Poutu event), when structures are unprotected by a tephra covering, roofs, especially, may be damaged and become weakened prior to lapilli fall and subsequent loading.

\section{Road network}

New Zealand state highways (SH) are controlled by Transit New Zealand, and include the state highways that pass through towns and cities. All other roads, urban and rural, are controlled by district authorities. During non-eruptive periods, the roads of the central North Island provide important transport links for economic and social activities. During or shortly after a period of volcanic eruption, regional and town transport corridors are critical for accessing other national lifelines and infrastructure, and for emergency services and evacuation.

Figure 7 shows SH1, 41, 46 and 47 of the central North Island. The Desert Road (SH1) has an approximate annual average daily traffic volume of 3420 vehicles (Transit New Zealand 2004). This number is low compared with other sections of SH1, but it is critical as a freight link. It is estimated that the closure of the Desert Road costs the New Zealand economy c. $\$ 8,000 / \mathrm{h}$ and if both SH1 and SH47, on opposite sides of the Tongariro National Park, are closed, \$23,000/h (Dalziell 1998). In proximal areas, state highways are the sole link between communities, because topography does not allow for a district rural road network.

Within the proximal impact zone, up to $80 \mathrm{~cm}$ of dominantly fine to medium sized lapilli will be deposited on sections of SH46 and SH47 and up to $60 \mathrm{~cm}$ on some sections of SH1. Table 6 shows ash depth against duration of road closure and traffic restrictions, based on observations from the 1980 Mt St Helens eruption (Dalziell 1998). The duration of a similar Poutu-style eruption may involve weeks to months of pre-eruptive activity, punctuated by sporadic eruptions depositing ash and lapilli, and with short periods of quiescence between the major eruptions phases. This would force periodic closures of SH1, SH46 and SH47 for days at a time (Table 6) disrupting north- and 
south-bound transport and freight distribution, although alternative routes may be available on the western side of Tongariro.

Nairn (2002) noted from both the Pinatubo 1991 and the Rabaul 1994 eruptions that dry volcanic ash can be driven on, but ash initially ejected wet, or that becomes wet, makes driving difficult because of the loss of traction. Coarser grained lapilli would most likely allow water to penetrate and permeate through the deposit. Difficulty, however, may arise from driving on this material. The weakness of some clasts such as pumice and scoria clasts identified from componentry analysis means they would be crushed under the weight of a vehicle and eventually thick accumulations may 'bog' the vehicle.

Deposits of the northeastern lobe show a lithic-rich layer at the base of the initial showerbed. Lithics at outcrops along SH46 are 2.5 - $3.5 \mathrm{~cm}$ maximum length. A similar Poutu-style eruption would distribute lithic clasts (maximum $3.5 \mathrm{~cm}, a$ axis length) on parts of SH1; the higher density of these clasts c. $2500-2700 \mathrm{~kg} / \mathrm{m}^{3}$ would impact with considerable force. Any traffic on these state highways during an eruption would be at risk from impact damage and the roads themselves may become damaged by potholing and abrasion.

Post-eruption roads can be scoured. The undercutting of roads, caused by drains blocked with pyroclastic material, happened, for example, in Rabaul (Nairn 2002). Bridges would most likely become buried by ash and lapilli, but they would be useable once cleared. Impacts from falling lithics may cause minor damage to bridge railing structures and signage. Bridges are, however, more susceptible to secondary lahars.

\section{Electricity Infrastructure, Supply and Reticulation}

Transpower has three $220 \mathrm{kV}$ transmission lines running north-south across the Central Plateau that form an integral part of the national electrical grid (Fig. 7). During the 1995-96 Ruapehu eruptions, fine ash caused a number of problems to electrical supply and reticulation (Johnston 1997a). Also within the proximal zone are two hydro-power generation stations, Rangipo (120 MW) and Tokaanu (240 MW), which can generate up to $4 \%$ of New Zealand's annual electrical generation (Genesis Power 2004), and which source water from a complex system of canals and tunnels feeding off the catchments of Ruapehu and of the Kaimanawa Range to the east. The 1995/96 Ruapehu eruption highlighted the vulnerability of these power stations to a small volume of ash, primarily by damaging turbine blades. 
A present-day Poutu-style eruption would deposit 30-50 cm of lapilli on the two power stations as well as depositing material in the lakes, canals and on dam structures associated with the power stations. The Rangipo power station and nearby related infrastructure would also be subject to lithic (2.0 - $2.5 \mathrm{~cm}, a$ axis length) impacts, on the basis of isopleth mapping (Fig. 8), causing impact damage to buildings and perhaps also to the dam and intake structures by pitting and abrasion. Posteruption, river systems will have continuous ash influx from catchments that will infill reservoirs, aggrading and clogging river systems for many years.

\section{Water supply and reticulation}

The water supply may be contaminated by ash, increasing turbidity and/or acidity of water bodies and reservoirs directly or indirectly open to the atmosphere (Johnston 1997a). In addition, ash particles may cause excessive wear of equipment and filters and short-circuit electrical components at water treatment plants (Johnston 1997b). The increased demand for water during clean-up operations will enhance these effects. Lahars may also break supply pipes.

The Turangi water source, treatment, and storage facility is located $2 \mathrm{~km}$ WSW of central Turangi. The spring source flows at a rate of $2897 \mathrm{~m}^{3} /$ day supplying 1850 homes and businesses of the Turangi community. The water is pumped by two electric pumps, with a diesel back-up pump, from the spring to the nearby treatment/pump station, during which the water remains completely enclosed from the atmosphere, so is reasonably secure. Outlying communities have roof collection systems, vulnerable to contamination from ashfall (Johnston 1997b), but resilient for extended periods if sealed prior to ashfall.

The treatment/pump station is located on the outskirts of Turangi; the pump house and treatment facilities are above the ground with some piping below the ground. The treatment process involves disinfection using chlorine with no need for the use of filters. The treatment station is not staffed and monitored by telemetry and only visited to change chlorine and fluoride supplies and routine maintenance. The building is constructed from concrete blocks and with a timber purlin-type roof construction and corrugated iron roof with a moderate pitch.

Water is stored in a pre-stressed 445,000 litre concrete reservoir and is covered by a concrete roof, built in the mid 1960s. The concrete roof of the reservoir structure itself has a live load rating of 98 
$\mathrm{kg} / \mathrm{m}^{2}$ (20 lb/sq ft) (Reservoir Plans, Taupo District Council 1964). Using the load calculation (Equation 1) of Johnston (1997a), the ash load pressure can be calculated using the density of deposited lapilli of the northeastern lobe and the lapilli thickness $\left(0.6 \mathrm{~m}\right.$; Fig. 7), as $355-534 \mathrm{~kg} / \mathrm{m}^{2}$ for dry ash or $479-720 \mathrm{~kg} / \mathrm{m}^{2}$ for wet ash (Table 5). These results are much greater than the rated engineered live load capacity of the water reservoir. Rearranging Equation 1 gives the maximum live load possible of ash and lapilli from the northwestern lobe as c. $11.5 \mathrm{~cm}$ (dry) and $8.5 \mathrm{~cm}$ (wet), respectively. Therefore, unless ash is cleared regularly from the top of the tank during a Poutu-style eruption, the load capacity of the Turangi reservoir will be exceeded with a potential failure, crippling water supply to households and emergency services during and after an eruption.

\section{Recreation and tourism}

The Tongariro National Park is a key locus of tramping, climbing, skiing and sightseeing in the North Island. In addition, Department of Conservation (DoC) huts are located around Mt Tongariro (Fig. 7). An eruption of this magnitude would have a dramatic effect on the park, burying it under $>60 \mathrm{~cm}$ of tephra. Within the boundaries of the Tongariro National Park, large lithic and pumice clasts (possibly hot) will fall, destroying the few structures. The ski fields of Mt Ruapehu could be subject to ashfall depending on wind direction. Whakapapa, in particular, although up-wind from the source in relation to the dominant wind direction, will experience an ashfall thickness of 5-10 $\mathrm{cm}$, and depending on the season, this could disrupt ski operations, similar to impacts during the Ruapehu 1995/96 eruption (Johnston 1997a).

\section{Forestry}

Local forests cover c. 32,600 ha, and support a significant proportion of the local workforce. The Rotoaira Forest plantation is located almost whollly within the proximal hazard zone on the slopes of Mt Tongariro and to the northwest (Fig. 7). The Lake Taupo Forest is located just SSE of Turangi, within the proximal zone, and continues to the northeast along the eastern shores of Lake Taupo into the medial zone. Most trees of the Lake Taupo Forest would receive $<40 \mathrm{~cm}$ of ash in a Poutu-style eruption scenario (Fig. 7), but it must be remembered that a slight change in wind direction or eruption intensity would change this considerably. A maximum tephra thickness of about $110 \mathrm{~cm}$ will be deposited on the Rotoaira Forest at its nearest location to the source, thinning out to $20 \mathrm{~cm}$ at the $25 \mathrm{~km}$ zone boundary (Fig. 7). Other impacts associated with the forest are dense lithics damaging trees and hot blocks of scoria/pumice falling, igniting vegetation. The Rotoaira Forest is located within the fall zone of both of these types of clasts (Figs. 7 and 8). 
Vucetich \& Pullar (1963) examined plant microfossils buried by tephra layers at a range of sites and concluded that a tephra depth of $>38 \mathrm{~cm}$ resulted in complete destruction of forests, $30-38 \mathrm{~cm}$ in almost complete destruction, and 23-30 cm in partial destruction. Eggler (1948) noted that pines with basal diameters of $10-30 \mathrm{~cm}$ survive best because they are strong enough to resist bending but supple enough to dump the ash and recover.

\section{Prison}

The Department of Corrections' minimum- to medium-security Hautu prison farm (Fig. 7), holding up to 422 prisoners plus staff, is located on the outskirts of Turangi (Department of Corrections, 2004). Figure 7 shows that $40 \mathrm{~cm}$ of material could potentially fall on the prison farm during a Poutu-style eruption. This amount of tephra material would likely interfere with the electrical security system, damage buildings and severely compromise farm activities. Prior evacuation of a large number of inmates to another secure location would need to be planned, taking transport and en-route security issues into account.

The New Zealand prison system in a civil emergency is required to be able and prepared to respond to an emergency ensuring the safety of staff and inmates as part of their National Policy on Emergency Response Plans (Blumenthal 2003). Although the prison system is aware of the potential situation, there is a potential lack of transport and police support during such a large scale emergency evacuation and the problem of finding a secure relocation site.

\section{MEDIAL AND DISTAL IMPACTS}

\section{Buildings and structures}

A Poutu-style eruption will affect the communities in the medial impact zone mainly around the shores of Lake Taupo, with impacts ranging from partial roof collapse to possibly mild damage such as guttering collapse in Taupo. In the distal zone, ash would be a nuisance and would have more passive impacts such as eventual corrosion of unprotected metals and some susceptible modern roof coverings.

\section{Roads and transport}

In the medial zone, driving would be impossible once the ash had fallen, as any thickness over 5 mm makes driving difficult (Barnard 2003). Roads could be cleared using methods and experience from the Ruapehu 1995/96 eruptions and from overseas eruptions, such as those of Sakurajima, Japan (Durand et al 2001). In the distal area, ash would be a nuisance, making road markings hard 
to see and driving difficult. Traffic would constantly stir up the ash, eventually moving it to the road verges. Airports would be closed, causing chaos to both international and domestic services, as happened during the 1995/96 Ruapehu eruption (Johnston et al 2000).

\section{Electricity infrastructure, supply and reticulation}

In the medial and distal zones there are a number of hydro-generation facilities along the Waikato River as well as thermal generation power stations with the network of high voltage lines connecting to the national grid. These facilities would be vulnerable to similar impacts that affected the power stations of the Central Plateau during the 1995/96 Ruapehu eruption. These affected the electrical reticulation systems of the Central Plateau including insulator flashovers of high voltage lines due to moist ash coating various equipment, and later flashovers at substations from clean-up operations (Johnston 1997a). Loss of electrical generation and supply from the North Island generation facilities and the potential reduction in transmission capacity to towns and cities will significantly disrupt public utilities of urban centres in the North Island. Studies by Gordon et al (2005) suggest computers within the power stations may be reasonably resilient with adequate protection. However if the ash is moist it is more likely to cause failure.

\section{Water supply and reticulation}

The Taupo District Council treats and distributes water from 21 water supply schemes at a number of different sites throughout the Taupo district. The majority of these water sources are lake supplied.

For communities located in the medial hazard zone around the shores of Lake Taupo (i.e., Taupo, Motuoapa and Kinloch), domestic water is sourced from Lake Taupo. Other centres in the medial zone, such as Mangakino, have a combination of spring/bore and river sources. Distal communities, such as Rotorua, Tokoroa and Hamilton, also have a combination of river and spring-fed sources.

Taupo Lake sources have treatment stations located close to the lake source. Treatment for the Taupo domestic water supply uses two methods: primary filtration using the Arkal method (Pelmar Engineering Ltd 2004) and secondary carbon filtration. The Arkal method uses a sequence of spinning disks held together by compressed air. Particulates are caught between the disks and, once clogged, are cleaned by releasing pressure and reverse flushing the system. The secondary carbon filtration method removes parasites but is susceptible to abrasion by ash particles because of the smaller screen size. Other treatment plants in the medial zone region use a range of processes such as flocculation, filtration, clarification, and disinfection. 
The reserve of water in Lake Taupo could be vulnerable to depletion if the lake source becomes contaminated, and the Taupo District Council could decide to reduce or stop water intake for the fear of ash damaging the plant. Water usage may increase, as locals wash their vehicles and property to clear ash, especially if this is promoted by local authorities, further making water supply in this area vulnerable to rapid depletion.

\section{EVACUATION}

The size and dispersal of material from a Poutu-style eruption will have serious implications for evacuation routes. The evacuation routes most impacted by tephra-fall will depend mainly on wind direction. Prior knowledge and preparedness by communities and especially local authorities is paramount when preparing for evacuation. Local authorities, such as the Taupo District Council have a formal and statuary obligation under the Waikato Civil Defence and Emergency Management Group plan, operating within the 2003 CDEM Act (http://www.ew.govt.nz/regionalservices/civil). In most situations they are likely to evacuate from Turangi in a northerly direction to a staging post in Taupo, or for a larger eruption to the Bay of Plenty (SH5) and/or to Waikato and Auckland (SH1). (P. Parker pers comm 16 December 2004). Preparation for housing evacuees is most important, especially with the potential for a number of people occupying a small space with little privacy.

Cole \& Blumenthal (2004) concluded that there is inadequate planning for long-term sheltering of people in high-risk regions. Evacuation planning in New Zealand is generally lacking and there is lack of co-ordination between agencies involved. Management and evacuation plans for transient populations must be prepared before an eruption and are especially important for the popular tourist destinations in the Turangi-Taupo area. To ensure community resilience it is essential that timely, accurate and clear information be disseminated both prior to and during any eruption (e.g. Becker et al 2001).

\section{POST ERUPTION}

\section{Ash and lapilli removal and disposal}

In proximal areas, if the recovery of communities and excavation of state highways is deemed economically viable, organised and systematic removal of material will need to be implemented. Initial removal will require heavy machinery such as front-end loaders, bulldozers and dump-trucks 
to remove the bulk of the material. Once the bulk of the coarse lapilli is removed, thicknesses $<5$ cm can be removed following the methods observed by Durand et al (2001) at Sakurajima. The studies of Johnston (1997a) and Gordon (2002) highlighted methods for the removal and the availability of machinery in a New Zealand situation. In medial and distal locations, the volume of material to be removed will still be great. Smaller grain-sized material will create an additional dust hazard when ash is dry.

The sheer volume of material deposited on roads alone in the fall region will create the problem of finding sufficiently large disposal sites. Ideally such sites would need to be located close to major areas of intense clean-up, because this will prevent reworking of material along already cleared transport routes and create quicker turn-around times for dump trucks. Councils would need to allot dump sites, and in some situations purchase potential dump sites so re-handling of material can be minimised. Dump sites need to be engineered using adequate stabilisation methods and the possible insertion of sprinklers, such as used to help dispose of 1980 Mt St Helens ash, to prevent it's remobilisation.

\section{CONCLUSIONS}

The impacts on infrastructure and utilities from ashfall of a Poutu-style subplinian eruption and associated clast impact could be devastating within a $25 \mathrm{~km}$ radius from the source, especially downwind of the eruption. Domestic and commercial buildings in Turangi and surrounding communities may have large thicknesses of dominantly lapilli-sized material settling on their roofs, which may potentially cause total or partial collapse from a Poutu-style eruption, especially if such material became wet. Communities closer to source may be subjected to dense lithic fall material, in addition to substantial ashfall thicknesses. Complete burial of roads will render them useless and involve labour-intensive rehabilitation at huge cost. Building and equipment damage may be the weakest link with any infrastructure or utility. The water treatment supply system in Turangi may become buried, but again the roofs of buildings are the weakest link, especially the water reservoir which has a long spanned roof. Electrical reticulation systems may be affected if the fines content from an eruption is high. Power stations will be affected primarily from roof collapse, shallowing of reservoirs, and mechanical equipment damage. Tourism in the area will be reduced and the ecosystem will be devastated. A full recovery of infrastructure and utilities from large volumes of tephra may not be economically feasible. Pine plantations will receive varying degrees of impact depending on proximity and wind strength to remove ash from branches. Relocation or the 
complete rebuilding of the Turangi township and other smaller communities and associated infrastructure may be the only option.

Medial areas may still be affected by heavy ashfall but in quantities that will allow eventual recovery. The distal impacts will be similar to those arising from the Ruapehu 1995/96 eruption except over a much larger area. Ashfall may cause weaker roofs to collapse, disrupt road transport, and interfere with the acidity and clarity of the water supply for Taupo and smaller lakeside communities. Lake water clarity will further be affected by the hosing of ash by residents from their properties into stormwater drains. Sweeping material from roofs is advised to save water and prevent ash runoff clogging the stormwater system. Fine ash that adheres to electrical infrastructure will have a similar impact to that of the Ruapehu 1995/96 event, with flashovers and disruption but on a much larger scale, possibly affecting most electrical generation stations in Waikato. Tourism may be greatly affected but some tourists may return to look at the effects of the eruption.

A Poutu-style eruption is likely from Tongariro some time in the future, and hazard management plans need to be reviewed and improved to cover such an eventuality.

\section{ACKNOWLEDGMENTS}

We thank the Department of Conservation for permission to map and collect samples from within the Tongariro National Park. Funding for the project came from FRST Contract UOC0207, and some logistic support for DWH came from the Mason Trust Fund, University of Canterbury. Professor Steve Weaver and Dr Graham Leonard read early versions of the manuscript, and Drs David Johnston and David Lowe reviewed the manuscript; all of their comments and suggested improvements are much appreciated.

\section{REFERENCES}

Barnard ST, 2003. Potential physical effects of any future 1886 type eruption from Tarawera volcano on the Bay of Plenty region. MSc. Thesis, University of Canterbury, Christchurch.

Becker J, Smith RT, Johnston D, Munro A 2001 Effects of the 1995-1996 Ruapehu eruptions on communities in central North Island, New Zealand, and people's perceptions of volcanic hazards after the event. The Australian Journal of Disaster and Trauma Studies 2001-1: 18pp.

Blong RJ, 1984. Volcanic hazard; a source book on the effects of eruptions. Sydney. Academic Press. 424 p. 
Blong RJ, 2003. Building damage in Rabaul, Papua New Guinea, 1994. Bulletin of Volcanology; 65: 43-54.

Blumenthal EC, 2003. Evacuation planning needed for any future rhyolite eruption from Tarawera volcano. MSc. Thesis, University of Canterbury, Christchurch.

Bronk Ramsey C 2001. Development of the radiocarbon calibration program OxCal. Radiocarbon 43: 355-363.

Cole JW 1978. Andesites of the Tongariro Volcanic Centre, North Island, New Zealand. Journal of Volcanology and Geothermal Research 3: 121-153.

Cole, JW, Blumenthal E 2004. Evacuate! What an order given because of appending eruption could mean to residents of the bay of Plenty. Tephra 21: 46-52.

Cole JW, Graham IJ, Hackett WR, Houghton BF, 1986. Volcanology and Petrology of Quaternary Composite Volcanoes of Tongariro Volcanic Centre, Taupo Volcanic Zone. In Smith I.E.M. (ed) Late Cenozoic Volcanism in New Zealand. The Royal Society of New Zealand Bulletin 23: $224-250$.

Cole JW, Stephenson TM, 1972. Calculation of the volume of a tephra deposit. In Cole, J.W., (ed). Distribution of High Alumina Basalts in Taupo Volcanic Zone, Geology Department, Victoria University of Wellington Publication, Wellington.

Dalziell EP, 1998. Risk assessment methods in road network evaluation: a study of the impact of natural hazards on the Desert Road, New Zealand. PhD Thesis, University of Canterbury, Christchurch.

Department of Corrections, 2004. Fact Sheets. Tongariro/Rangipo Prison. $>$ www.corrections.govt.nz/public/aboutus/factsheets/prisons/tongarirorangipo.html< [Accessed 8 August 2004].

Donoghue SL, Stewart RB, Palmer AS 1991. Morphology and chemistry of olivine phenocrysts of Mangamate Tephra, Tongariro Volcanic Centre, New Zealand. Journal of the Royal Society of New Zealand 21:225-236.

Durand M, Gordon K, Johnston DJ, Lorben R, Poirot T, Scott J, Shephard B, 2001. Impacts of, and responses to ashfall in Kagoshima from Sakurajima Volcano - lessons for New Zealand. Institute of Geological and Nuclear Sciences Report, 2001/20. 66 p.

Eggler WA, 1948. Plant communities in the vicinity of the volcano El Paricutin, Mexico after two and a half years of eruption. Ecology. 29: 415-436.

Fierstein J, Nathenson M, 1992. Another look at the calculation of fallout tephra volumes. Bulletin of Volcanology. 54: 156-167. 
Genesis Power, 2004. Genesis Power - Tongariro Power Scheme. [Internet] Available from: www.genesispower.co.nz/genesis/index.cfm?D54C30AF-50BA-1DC3-65AE22844A205B03\#tpd< [Accessed June 9 2004]

Gordon K, 2002. The effects of volcanic ash on components of infrastructure. MSc Thesis, University of Canterbury, Christchurch.

Hajdas I, Lowe DJ, Newnham RM, Bonani G, 2006. Timing of the late-glacial climate reversal in the Southern Hemisphere using high-resolution radiocarbon chronology for Kaipo bog, New Zealand. Quaternary Research 65: 340-345.

Hobden BJ, 1997. Modelling magmatic trends in time and space: Eruptive and magmatic history of the Tongariro Volcanic Complex, New Zealand. PhD. Thesis, University of Canterbury, Christchurch.

Hobden BJ, Houghton BF, Davidson JP, Weaver SD, 1999. Small and short-lived magma batches at composite volcanoes: time windows at Tongariro volcano, New Zealand. Journal of the Geological Society, London. 156: 865-868.

Inman 1952. Measures for describing the size distribution of sediments. Journal of Sedimentary Petrology 22: 125-145.

Johnston D, 1997a. Physical and social impacts of past and future volcanic eruptions in New Zealand. PhD. Thesis, Massey University, Palmerston North.

Johnston D, 1997b. The impacts of recent falls of volcanic ash on public utilities in two communities in the United States of America. Institute of Geological and Nuclear Science Ltd, Lower Hutt. Report 97/5. 23 p.

Johnston D, Houghton BF, Neall VE, Ronan KR, Paton D, 2000. Impacts of the 1945 and 19951996 Ruapehu eruptions, New Zealand; an example of increasing societal vulnerability. Geological Society of America Bulletin. 112: 720-726.

Lowe DJ, 1988. Stratigraphy, age, composition, and correlation of late Quaternary tephras interbedded with organic sediments in Waikato lakes, North Island, New Zealand. New Zealand Journal of Geology and Geophysics. 31(2): 125-165.

Lowe DJ, Hogg AG, Green JD, Boubee JAT, 1980. Stratigraphic and chronology of late Quaternary tephras in Lake Maratoto, Hamilton, New Zealand. New Zealand Journal of Geology and Geophysics. 23 (4): 481-485.

Lowe DJ, Shane PAR, Alloway BV, Newnham RM, in press. Fingerprints and age models for widespread New Zealand tephra marker beds erupted since 30,000 years ago: a framework for NZ-INTIMATE. Quaternary Science Reviews

Mathews WH, 1967. A contribution to the geology of the Mount Tongariro massif, North Island, New Zealand. New Zealand Journal of Geology and Geophysics. 10 (4): 1027-1038. 
McCormac G, Hogg AG, Blackwell PG, Buck CE Higham TFG, Reimer PJ 2004. SHCal04 Southern Hemisphere calibration, 0-11 cal kyr BP. Radiocarbon 46: 1087-1092.

Nairn I, 2002. The effects of volcanic ash (tephra) on road and airport surfaces. Institute of Geological and Nuclear Sciences Ltd. Lower Hutt. Report 2002/13. 32 p.

Nairn IA, Kobayashi T, Nakagawa M, 1998. The $\sim 10 \mathrm{ka}$ multiple vent pyroclastic eruption sequence at Tongariro Volcanic Centre, Taupo Volcanic Zone, New Zealand: Part 1. Eruptive processes during regional extension. Journal of Volcanology and Geothermal Research. 86 (14): $19-44$.

Pelmar Engineering Ltd, 2004. Arkal Filtration Systems. [Internet] Available from: >www.processcontrols.com/Pelmar/Arkal.html < [Accessed January 21 2005]

Pomonis A, Spence R,d Baxter PJ, 1999. Risk assessment of residential buildings for an eruption of Furnas Volcano, Sao Miguel, the Azores. Journal of Volcanology and Geothermal Research. 92: 107-131.

Pyle DM, 1989. The thickness, volume and grainsize of tephra fall deposits: Bulletin of Volcanology. 51: 1-15.

Pyle DM, 1995. Assessment of the minimum volume of tephra fall deposits; Journal of Volcanology and Geothermal Research. 69: 379-382.

Shane P 2007. Comment on: "Probabilistic tephra fall simulation for the Auckland region, New Zealand by Magill et al. 2006". Journal of Volcanology and Geothermal Research 159: 421422.

Siebert L, Simkin, T, 2002-. Volcanoes of the World: An illustrated catalog of Holocene volcanoes and their eruptions. Smithsonian Institution, Global Volcanism Program. Digital Information Series GVP-3. Available from: >http://www.volcano.si.edu/world.htm< [Accessed April 3 2005].

Sparks RSJ, 1986.The dimensions and dynamics of volcanic eruption columns. Bulletin of Volcanology. 48: 3-15.

Spence RJS, Pomonis A, Baxter PJ, Coburn AW, White M, Dayrit M, Field Epidemiology Training Program Team, 1996. Building damage caused by the Mount Pinatubo eruption of June 15, 1991. In Newhall, C.G. and Punongbayan, R.S. (eds). Fire and mud; eruptions and lahars of Mount Pinatubo, Philippines. Philippine Institute of Volcanology and Seismology. London, University of Washington Press: 1055-1061.

Statistics New Zealand. Census, 2001. [Internet] >www.stats.govt.nz/census/default.htm $<$ [Accessed June 9 2004] 
Topping WW, 1973. Tephrostratigraphy and Chronology of Late Quaternary Eruptives from the Tongariro Volcanic Centre, New Zealand. New Zealand Journal of Geology and Geophysics, 16: 397-423.

Transit New Zealand, 2004. State Highway Traffic Report. Traffic Design Group Ltd. [Internet] Available from: >www.transit.govt.nz/technical_information/index.jsp $<28$ p. [Accessed February 15 2005]

Vucetich C, Pullar W 1963. Ash beds and soils in the Rotorua district. Proceedings of the New Zealand Ecological Society 10: 2-9.

Walker GPL, 1973. Explosive volcanic eruptions - a new classification scheme: Geologische Rundschau 62: 431-446.

Walker GPL, 1980. The Taupo pumice: Product of the most powerful known (ultraplinian) eruption? Journal of Volcanology and Geothermal Research 8: 69-94.

\section{FIGURES}

1. Recent and pre-historic volcanic vents of Tongariro volcano. Adapted from Cole (1978).

2. Isopach map of the Poutu Lapilli showing thickness and distribution of the deposit. Insert shows the $0-25 \mathrm{~km}, 25-100 \mathrm{~km}$ and $>100 \mathrm{~km}$ impact zones discussed within the text.

3. Isopleth maps, map A (pumice) and B (lithic) for the Poutu Lapilli. The lithic isopleths were used for eruption column volume and height calculations using the methods of Pyle (1989) by closing the isopleths in the southeastern area and assuming no lobe in this direction.

4. Photograph of the Poutu Lapilli at location T6, close to location T2 and the lobe axis of the northeastern lobe. Five showerbeds are shown with the erosional upper boundary. Length of ruler $73 \mathrm{~cm}$.

5. Size distribution, componentry, stratigraphic column and grain size parameters (Inman 1952) for section T2 of the northeastern lobe of the Poutu Lapilli. $\mathrm{Md}=$ median diameter in $\mathrm{mm} ; \sigma \varphi=$ sorting value, $0-1$ very well sorted to $>4$ very poorly sorted, $<2 \mathrm{~mm}=$ ash percentage.

6. Revised classification scheme of $b_{c} / b_{t}$ vs. $b_{t}$ from Pyle (1989) based on Walker (1973) shows that two of the three main lobes, the eastern and northwestern, plot within the subplinian field, the northeastern is classified as a plinian eruption according to this scheme.

7. Infrastructure, utilities and communities located within the Turangi area within the proximal $(0-25 \mathrm{~km})$ impact zone with isopachs of the Poutu Lapilli deposit superimposed. Grid reference is based on the NZMS 260 map series. 
8. Isopleth map of lithics ( $a$ axis clast length) from the Poutu Lapilli eruption superimposed on the present day communities, utilities and infrastructure. Grid reference is based on the NZMS 260 map series.

9. Typical housing style of ex-Tongariro Power Development houses in Turangi, this style accounts for c. $45 \%$ of the homes in Turangi township.

\section{TABLES}

1. Tephrochronology of the $<10 \mathrm{ka}$ tephra formations and selected members erupted from and outcropping around Tongariro volcano. ${ }^{14} \mathrm{C}$ based on the old (Libby) half life. Calibrated ages based on Hajdas et al (2006) and Lowe et al (in press).

2. Calculated lobe parameters used to find the volume of eruptive material for each individual lobe. $-\mathrm{k}$ is the slope, the $\mathrm{R}^{2}$ value is the coefficient determinant and is recognised as a measure of how well data fits to a trend line, one is a perfect relationship, $b_{t}$ is the thickness half distance, $\mathrm{T}_{0}$ is the thickness at source, $\mathrm{V}$ is the volume, $\mathrm{T}_{\text {Last }}$ is the last reliable isopach include in the calculation and $\mathrm{V} / \mathrm{V}_{\mathrm{TOT}}$ is the $\%$ of material constrained to the last isopach. Based on Pyle $(1989,1995)$.

3. Table showing the variables and results using the methodology of Pyle (1989) for calculating eruption column height; $-\mathrm{k}$ is the slope, the $b_{c}$ value is the clast half distance, $b_{t}$ is the thickness half distance, $b_{c} / b_{t}$ is the half distance ratio, $\mathrm{H}_{b}$ is column buoyancy height while $\mathrm{H}_{\mathrm{t}}$ is the total column height calculated using a factor of c. 0.25 from Sparks (1986). Values in brackets are rounded values.

4. Selected major urban and rural areas that may be impacted by a Poutu-style eruption with distance from vent (Ngauruhoe normalised), estimated ash thickness, population and households of those areas. Data from: Population and households statistics based on the 2001 Census, Statistics New Zealand.

5. Load capacity determination for the Turangi residential buildings and comparison to loads of the 1994 Rabaul eruption from Blong (2003). Thicknesses of the ash from the Rabaul eruption have been converted using Table 1 from Blong (2003) where they have been approximated to the corresponding ash load pressure. Ash load pressures $\left(\mathrm{kN} / \mathrm{m}^{3}\right)$ have been converted to $\mathrm{kg} / \mathrm{m}^{2}$ for comparison in this study. Gravitational acceleration used $=9.8 \mathrm{~m} / \mathrm{s}^{2}$.

6. Estimated duration of road closures and additional traffic restrictions relating to ashfall thickness. Adapted from Dalziell (1998). 
Table 1

\begin{tabular}{|c|c|c|c|c|}
\hline FORMATION & MEMBERS & OTHER SOURCES & AGE BP $\left({ }^{14} \mathrm{C}\right)$ & $\frac{\text { CALCULATED AGE }}{\text { (Calc. Years BP) }}$ \\
\hline \multicolumn{5}{|l|}{ Ngauruhoe/Tufa Trig } \\
\hline & & Taupo Pumice (TVC) & $1850 \pm 10$ & $1718 \pm 30$ \\
\hline \multicolumn{5}{|l|}{ Mangatawai } \\
\hline \multicolumn{5}{|l|}{ Papakai } \\
\hline & & Waimihia Tephra (TVC) & $3280 \pm 20$ & $3410 \pm 40$ \\
\hline \multicolumn{5}{|l|}{ Papakai } \\
\hline & & Opepe Tephra (TVC) & $9050 \pm 40$ & $10075 \pm 155$ \\
\hline \multirow[t]{8}{*}{ Mangamate } & Poutu Lapilli (PM6) & & c. 9700 & c. 11000 \\
\hline & Wharepu Tephra (PM5) & & & \\
\hline & Ohinepango Tephra (PM4b) & Poronui Tephra (TVC) & $9810 \pm 50$ & $11190 \pm 80$ \\
\hline & Waihohonu Lapilli (PM4a) & & & \\
\hline & unnamed tephra (UT1) & & & \\
\hline & Oturere Lapilli (PM3) & & & \\
\hline & Te Rato Lapilli (PM2) & & & \\
\hline & unnamed tephra (UT2) & & $9780 \pm 170$ & \\
\hline Pahoka & Pahoka Tephra (PM1) & Karapiti Tephra (TVC) & $9820 \pm 80$ & $11410 \pm 90$ \\
\hline Okupata & & & $10,000-9,800$ & $11620 \pm 190$ \\
\hline
\end{tabular}

Table 2

\begin{tabular}{|l|c|c|c|c|c|c|c|}
\hline \multicolumn{1}{|c|}{ UNIT } & $-\mathbf{k}$ & $\mathbf{R}^{\mathbf{2}}$ & $\mathbf{b}_{\mathbf{t}}(\mathbf{k m})$ & $\mathbf{T}_{\mathbf{0}} \mathbf{( \mathbf { c m } )}$ & $\left.\mathbf{V} \mathbf{( k m}^{\mathbf{3}}\right)$ & $\mathbf{T}_{\text {Last }}$ & $\mathbf{V}_{\mathbf{V}} \mathbf{V}_{\text {TOT }}$ \\
\hline Northwestern & -0.0982 & 0.9852 & 3.982 & 164 & .340 & 0.2 & .62 \\
Northeastern & -0.1188 & 0.9886 & 3.291 & 203 & .288 & 0.3 & .57 \\
Eastern & -0.0889 & 0.9474 & 4.398 & 146 & .369 & 0.3 & .47 \\
\hline Total & - & - & - & - & .997 & - & - \\
difference & - & - & - & - & .093 & - & - \\
\hline
\end{tabular}

Table 3

\begin{tabular}{|c|c|c|c|c|c|c|c|}
\hline LOBE & Clast & $-\mathbf{k}$ & $\mathbf{b}_{\mathbf{c}}$ & $\mathbf{b}_{\mathbf{t}}$ & $\mathbf{b}_{\mathbf{c}} / \mathbf{b}_{\mathbf{t}}$ & $\begin{array}{c}\mathbf{H}_{\mathbf{b}} \\
(\mathbf{k m})\end{array}$ & $\begin{array}{c}\mathbf{H}_{\mathbf{t}} \\
(\mathbf{k m})\end{array}$ \\
\hline Northwest & lithic & -0.1760 & 2.83 & 3.98 & 0.710 & 18.5 & $25.9(26)$ \\
\hline Northeast & lithic & -0.2197 & 3.79 & 3.30 & 1.14 & $23.1(23)$ & $32.3(32)$ \\
\hline Eastern & lithic & -0.1515 & 1.96 & 4.40 & 0.445 & $15.9(16)$ & $22.3(22)$ \\
\hline
\end{tabular}


Table 4

\begin{tabular}{|l|c|c|c|c|}
\hline \multicolumn{1}{|c|}{ Town/Area } & $\begin{array}{c}\text { Distance } \\
\text { from vent } \\
\mathbf{( k m )}\end{array}$ & $\begin{array}{c}\text { Ash } \\
\text { thickness } \\
\mathbf{( c m )}\end{array}$ & Population & Households \\
\hline Rangipo district area & 20 & $70-50 \mathrm{~cm}$ & 270 & 36 \\
\hline Turangi urban area & 25 & $60-50 \mathrm{~cm}$ & 3,441 & 2,241 \\
\hline Owhango urban area & 25 & $5-0 \mathrm{~cm}$ & 207 & 81 \\
\hline Taumarunui urban area & 45 & $8-5 \mathrm{~cm}$ & 2,640 & 969 \\
\hline Taupo urban area & 65 & $10-5 \mathrm{~cm}$ & 20,310 & 7,371 \\
\hline Taupo district area & - & Max-5 cm & 31,521 & 11,262 \\
\hline Te Kuiti urban area & 97 & $7-5 \mathrm{~cm}$ & 4,374 & 1,563 \\
\hline Tokoroa urban area & 105 & $8-5 \mathrm{~cm}$ & 14,427 & 4,809 \\
\hline Rotorua urban area & 125 & $6-3 \mathrm{~cm}$ & 52,608 & 18,336 \\
\hline Hamilton urban area & 150 & $5-3 \mathrm{~cm}$ & 138,792 & 48,558 \\
\hline Auckland region & 250 & $<1 \mathrm{~cm}$ & $1,158,891$ & 389,658 \\
\hline
\end{tabular}

Table 5

\begin{tabular}{|c|c|c|c|c|}
\hline & \multicolumn{2}{|c|}{$\begin{array}{l}\text { Ash thickness } \\
\text { (cm) }\end{array}$} & $\begin{array}{l}\text { Density } \\
\left(\mathbf{k g} / \mathbf{m}^{3}\right)\end{array}$ & $\begin{array}{c}\text { Ash load } \\
\text { Pressure range } \\
\text { (kPa) }\end{array}$ \\
\hline \multirow{2}{*}{$\begin{array}{l}\text { Turangi roofs } \\
\begin{array}{c}\text { (Poutu-style } \\
\text { eruption) }\end{array}\end{array}$} & \multicolumn{2}{|c|}{$40-60$} & $\begin{array}{c}888.66 \\
\text { (NE dry lapilli) }\end{array}$ & $\begin{array}{c}3.48-5.23 \\
\left(\sim 355-534 \mathrm{~kg} / \mathrm{m}^{2}\right)\end{array}$ \\
\hline & \multicolumn{2}{|c|}{$40-60$} & $\begin{array}{c}1200.39 \\
\text { (NE wet lapilli) }\end{array}$ & $\begin{array}{c}4.70-7.06 \\
\left(\sim 479-720 \mathrm{~kg} / \mathrm{m}^{2}\right)\end{array}$ \\
\hline \multirow{3}{*}{$\frac{\text { Rabaul } 1994}{\begin{array}{c}\text { (observed } \\
\text { failure) }\end{array}}$} & Min & $\sim 13-55$ & \multirow{3}{*}{-} & $204-510 \mathrm{~kg} / \mathrm{m}^{2}$ \\
\hline & Max & $\sim 90$ & & $1531 \mathrm{~kg} / \mathrm{m}^{2}$ \\
\hline & Ave & $\leq 46$ & & $>764 \mathrm{~kg} / \mathrm{m}^{2}$ \\
\hline
\end{tabular}


Table 6

\begin{tabular}{|c|c|c|}
\hline Ash depth (mm) & $\begin{array}{c}\text { Road closure duration } \\
\text { (days) }\end{array}$ & $\begin{array}{c}\text { Traffic restrictions duration } \\
\text { (days) }\end{array}$ \\
\hline $0-2$ & 0 & $1-3$ \\
\hline $2-5$ & $0-1$ & $1-3$ \\
\hline $5-7$ & $0-1$ & $2-4$ \\
\hline $7-10$ & $1-2$ & $2-4$ \\
\hline $10-15$ & $1-2$ & $5-8$ \\
\hline $15-20$ & $1-3$ & $5-8$ \\
\hline $20-30$ & $2-4$ & $8-12$ \\
\hline $30-50$ & $3-6$ & $8-12$ \\
\hline $50-75$ & $4-8$ & $8-12$ \\
\hline
\end{tabular}


Figure 1.

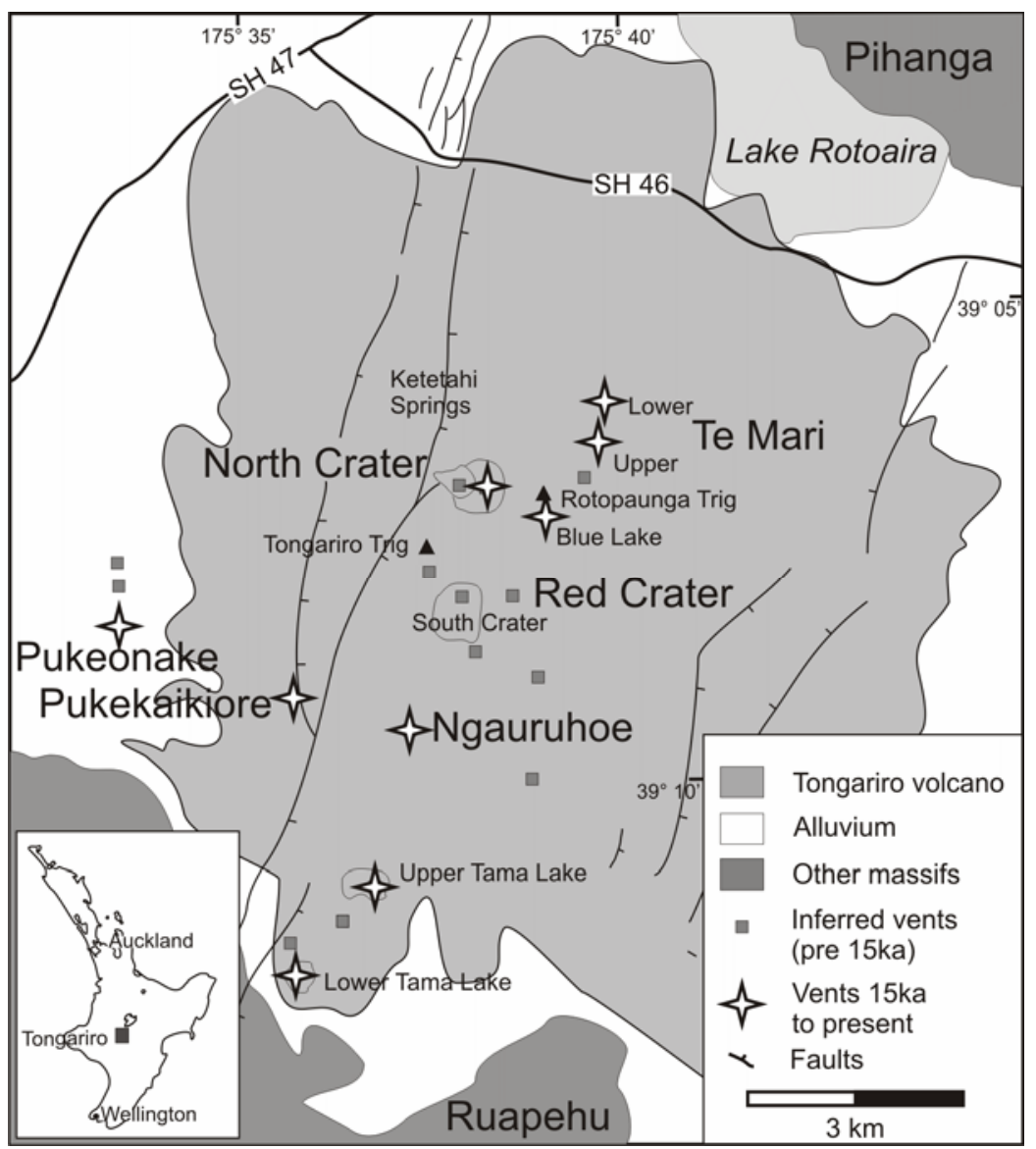


Figure 2.

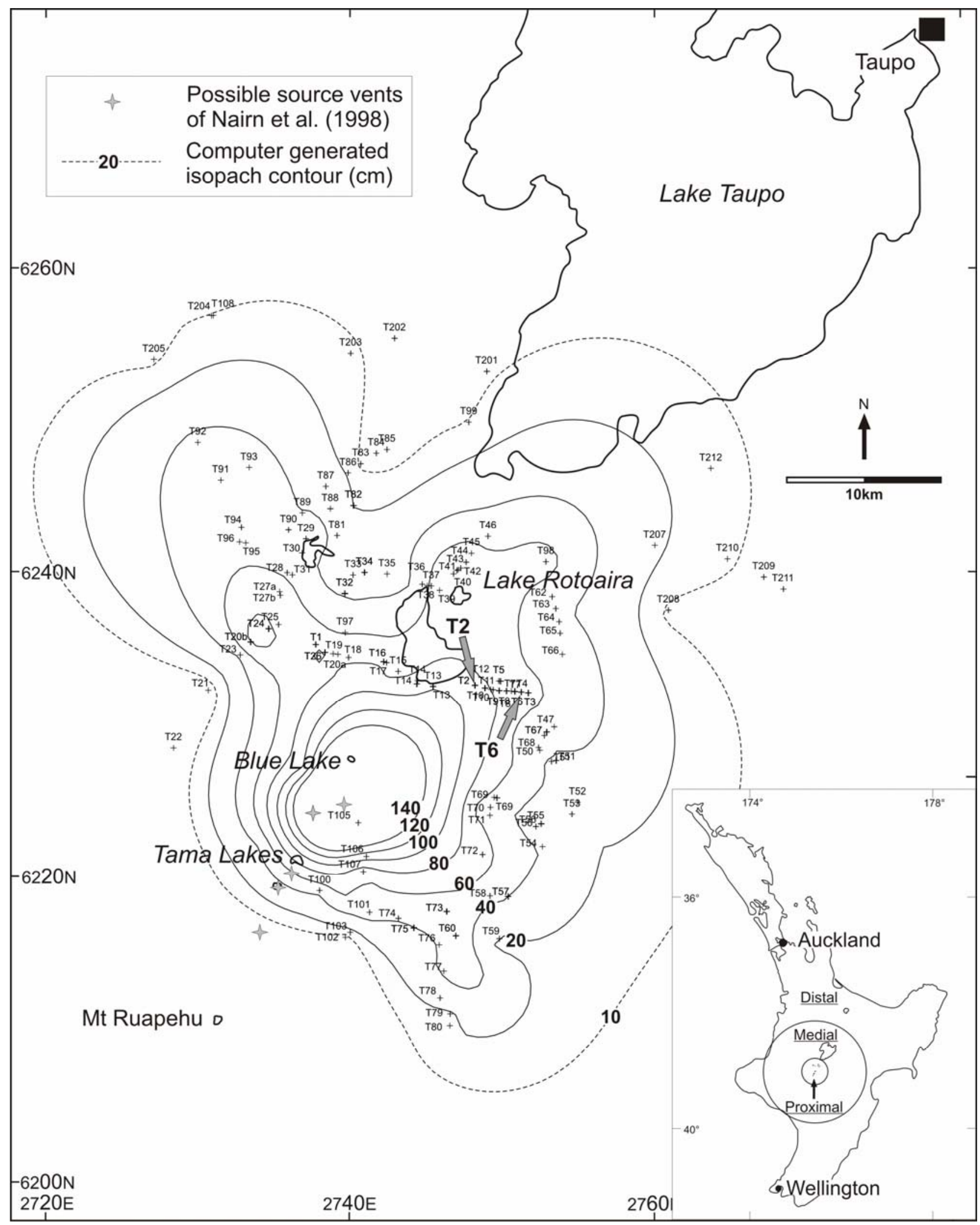


Figure 3.
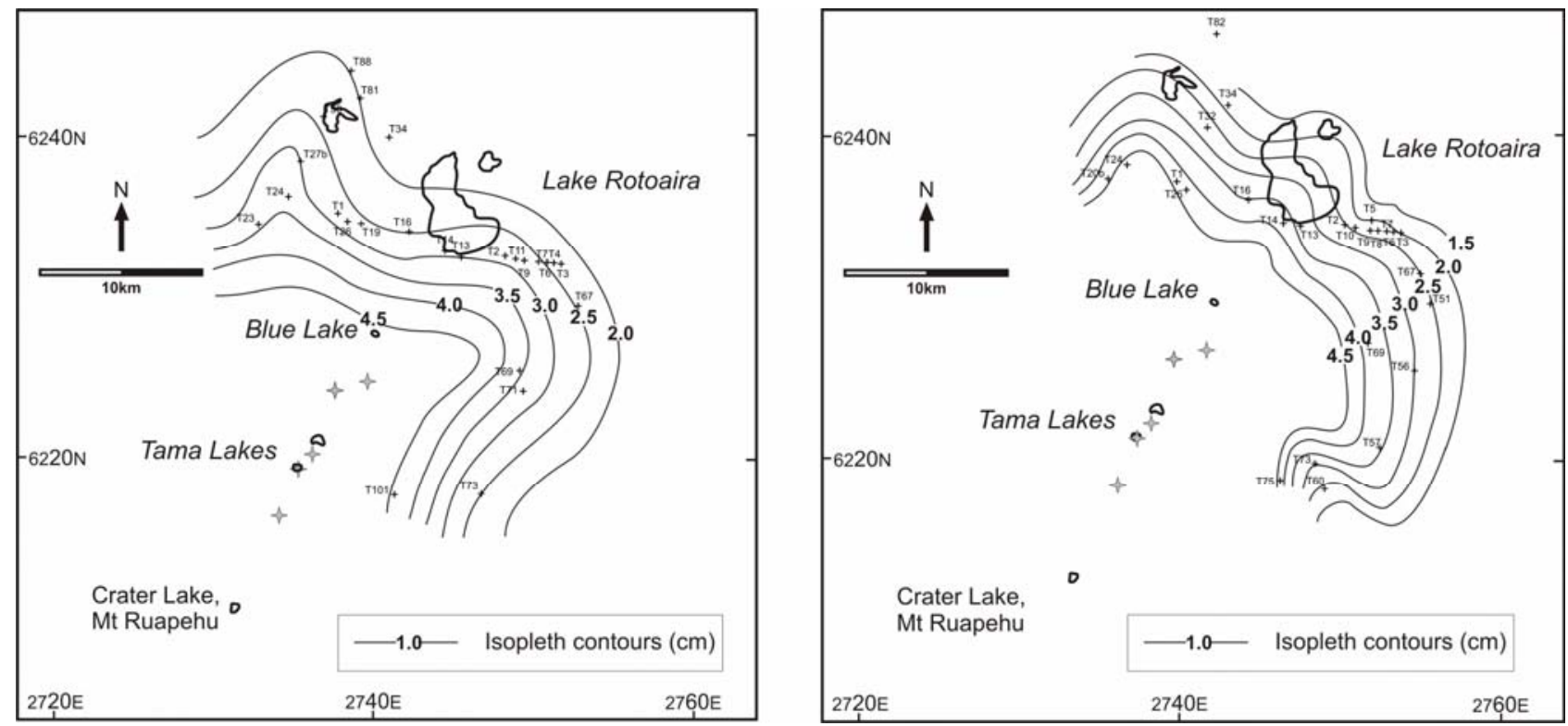

Figure 4.

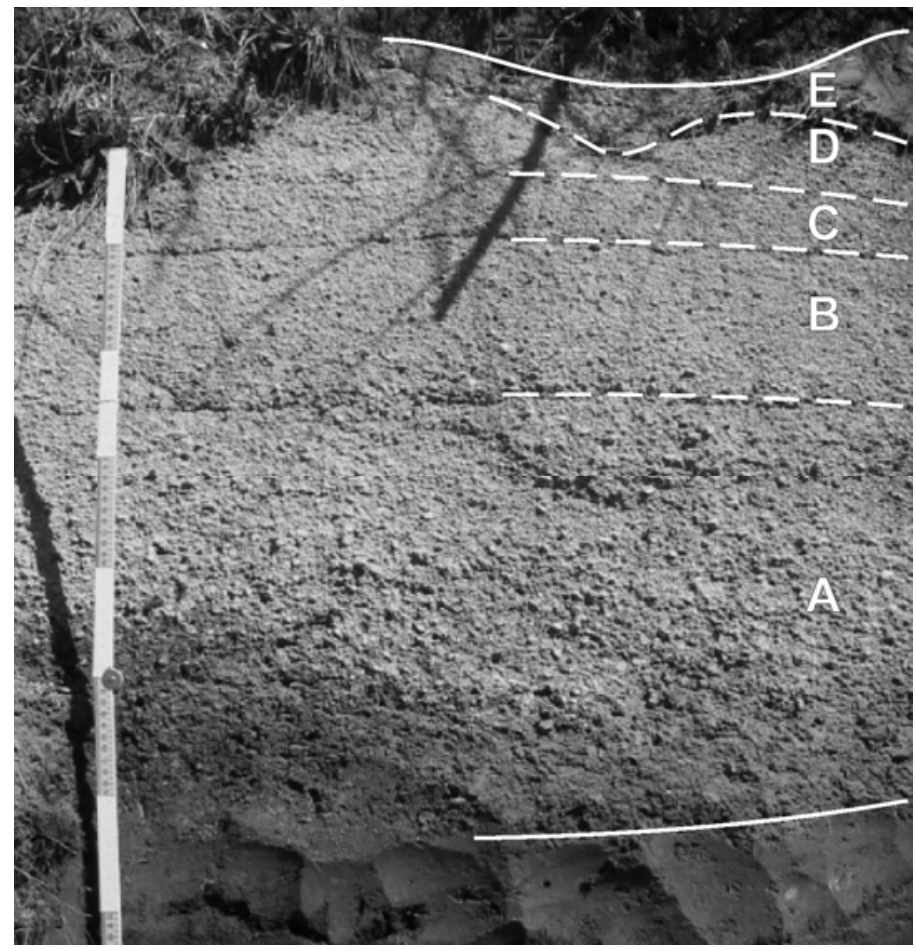


Figure 5 
LOCATION T2

(T19 482324)
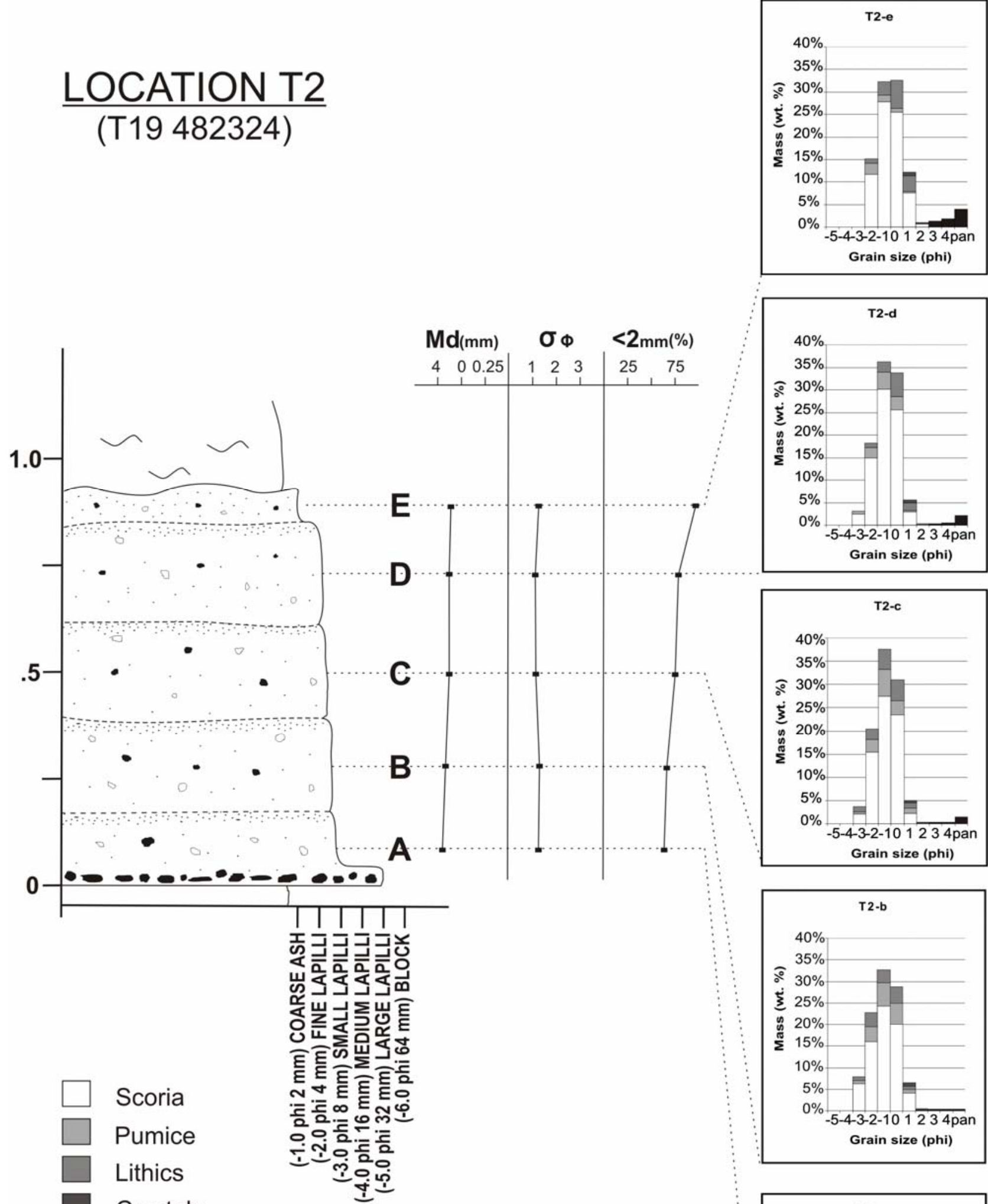

Crystals

Non-componentry
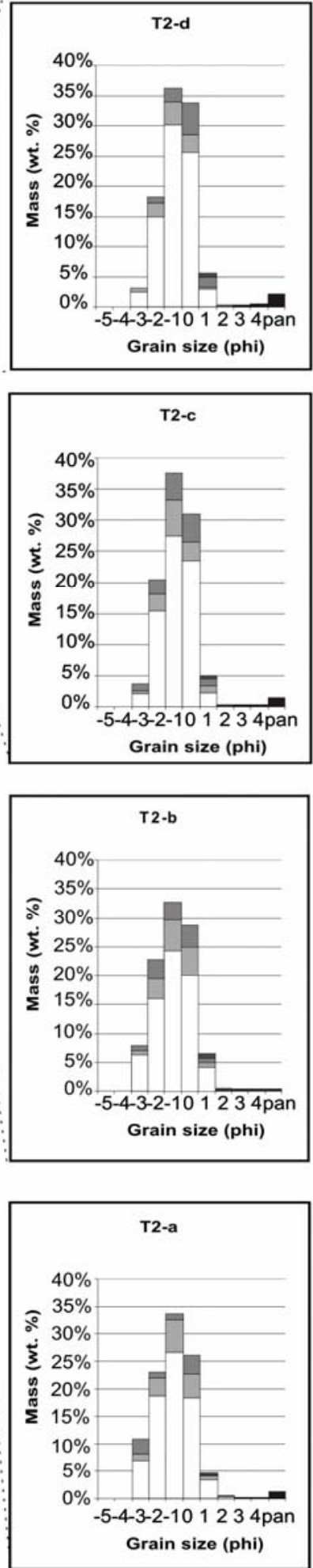
Figure 6.

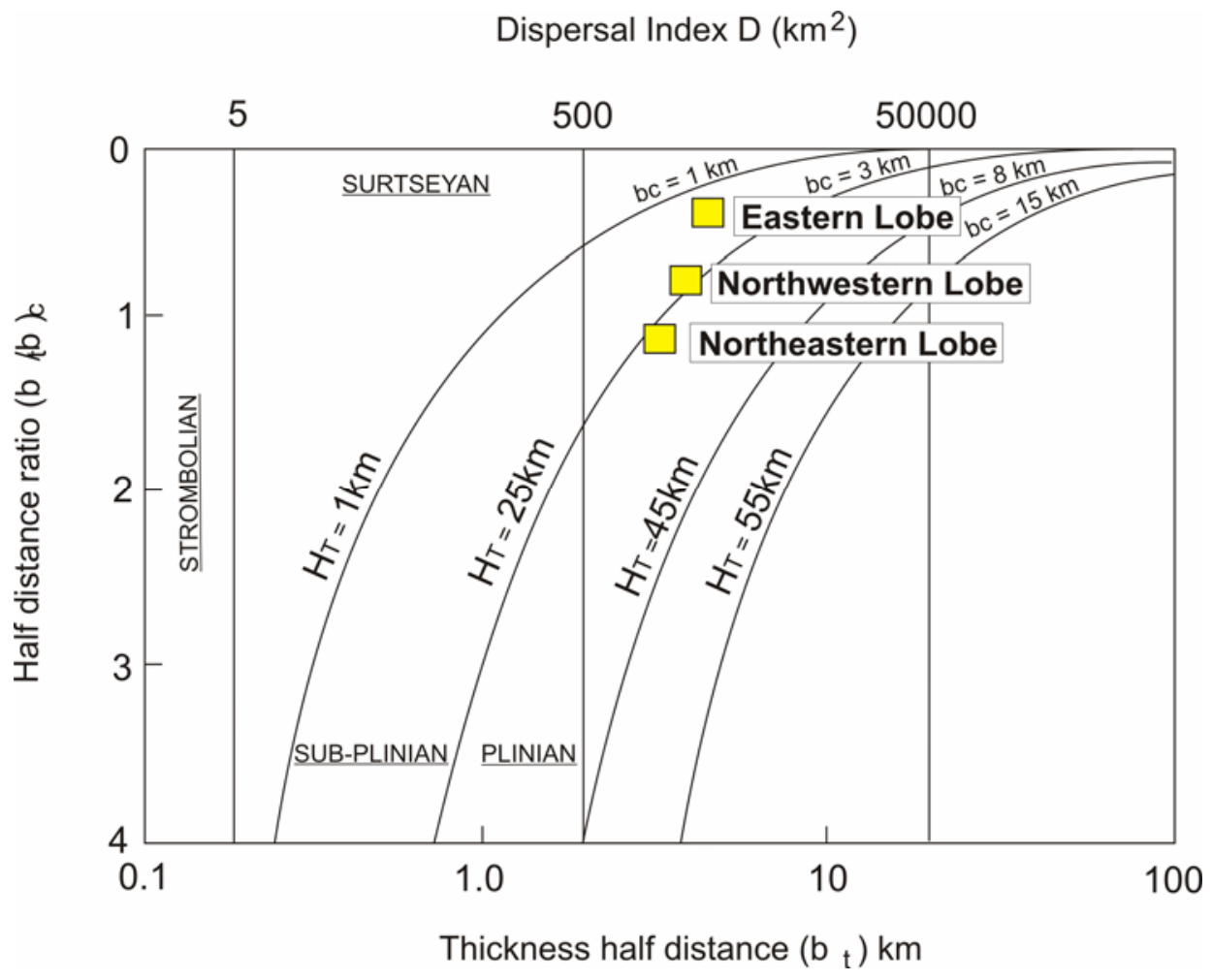


Figure 7.

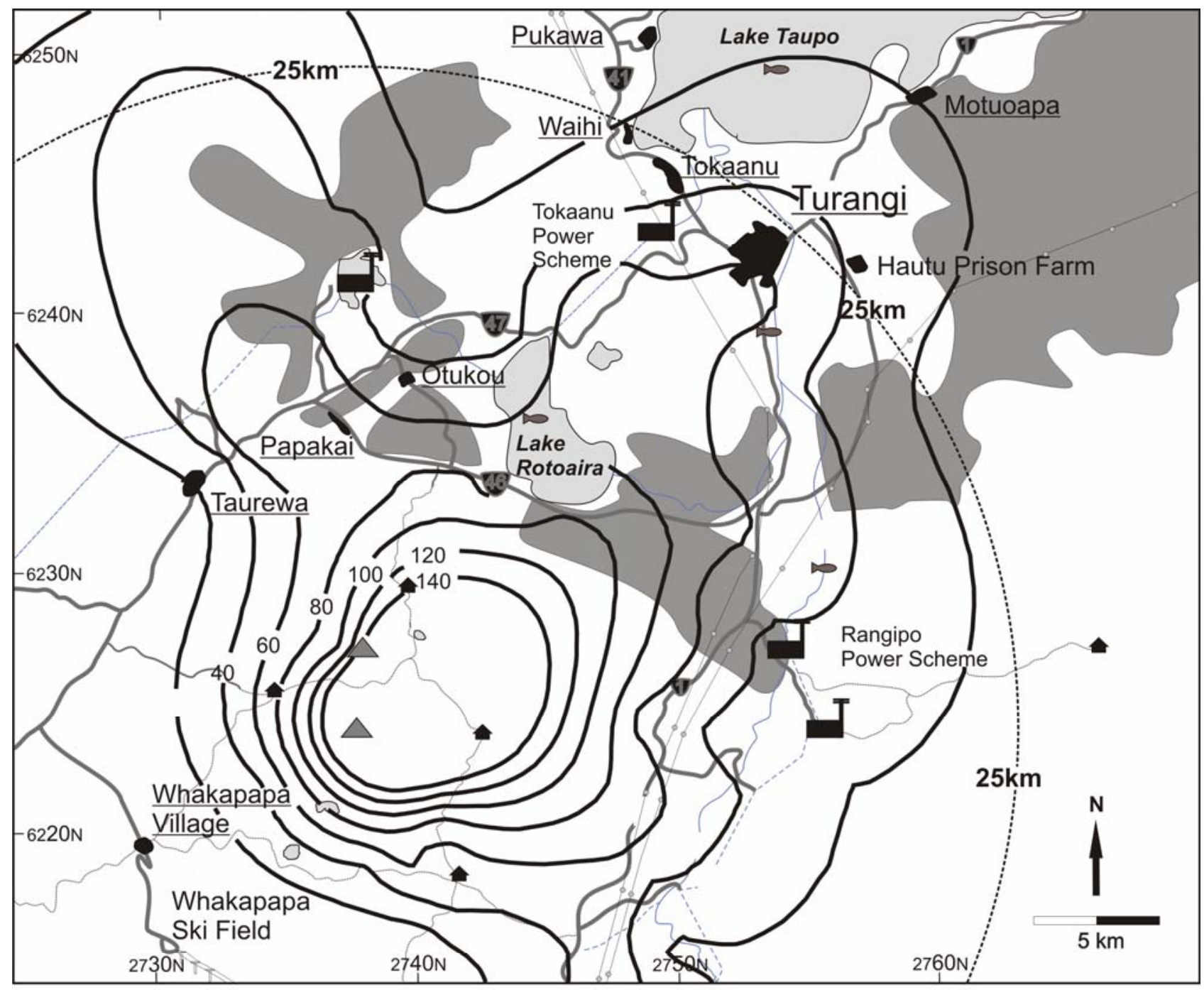

\begin{tabular}{|c|c|c|c|c|c|}
\hline 6 & State Highways & Volcano Summits & Lakes & Walking Track & Hydro-Tunnel \\
\hline & DoC Huts & $\begin{array}{l}\text { Hydro-Generation } \\
\text { Stations and Dams }\end{array}$ & Urban Areas & Roads & Rivers \\
\hline$\infty$ & Fishing & $\begin{array}{l}\text { High-Voltage } \\
\text { Transmission Lines }\end{array}$ & Commercial Pine Plantations & \multicolumn{2}{|c|}{ Isopleth measurements are in $\mathrm{cm}$} \\
\hline
\end{tabular}


Figure 8.

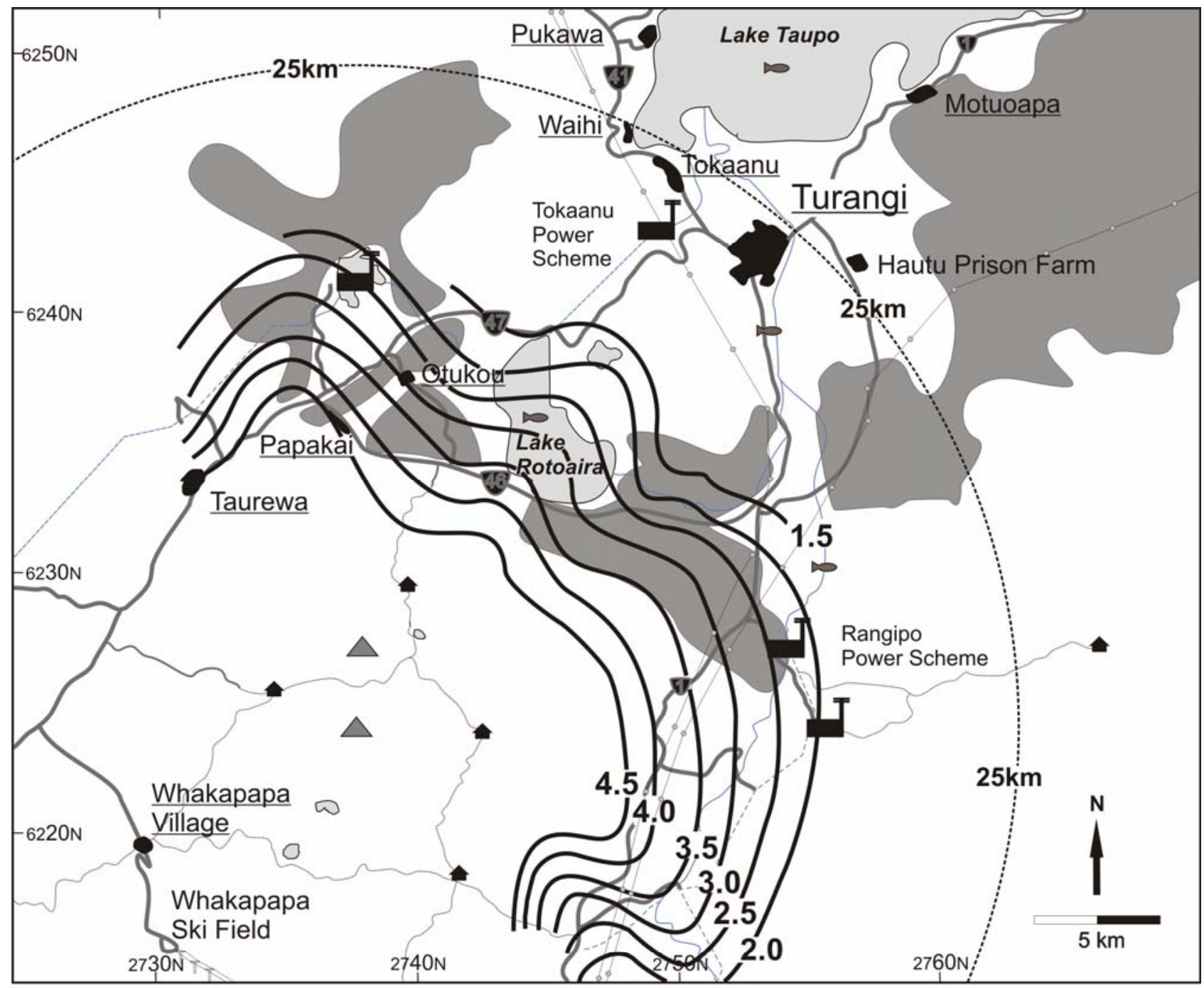

\begin{tabular}{|c|c|c|c|c|c|}
\hline 6 & State Highways & Volcano Summits & Lakes & Walking Track & Hydro-Tunnel \\
\hline & DoC Huts & $\begin{array}{l}\text { Hydro-Generation } \\
\text { Stations and Dams }\end{array}$ & Urban Areas & Roads & Rivers \\
\hline$\infty$ & Fishing & $\begin{array}{l}\text { High-Voltage } \\
\text { Transmission Lines }\end{array}$ & Commercial & Isopleth & ents are in $\mathrm{cm}$ \\
\hline
\end{tabular}

Figure 9.

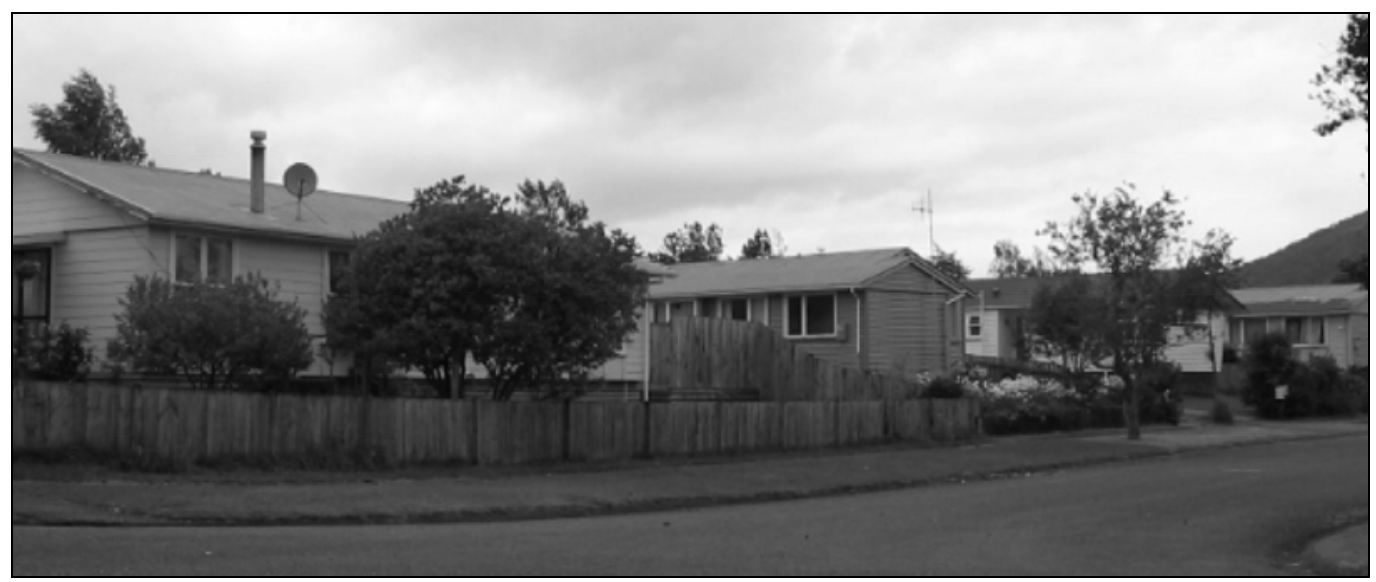

